\title{
STATUS SEROLOGIS TIDAK MEMPENGARUHI PROFIL HEMATOLOGI ANAK TERINFEKSI VIRUS DENGUE
}

\author{
SEROLOGICAL STATUS DO NOT AFFECT \\ HEMATOLOGICAL PROFILES IN CHILDREN WITH DENGUE VIRUS INFECTION
}

\author{
Safari Wahyu Jatmiko \\ Bagian Patologi KlinikFakultas Kedokteran \\ Universitas Muhammadiyah Surakarta \\ Korespondensi: Safari Wahyu Jatmiko: safari.wahyu@ums.ac.id
}

\begin{abstract}
ABSTRAK
Antibodi anti dengue bersifat autoantibodi yang bisa merusak self antigen. Respon imun humoral terhadap DENV adalah terbentuknya IgM dan IgG yang spesifik terhadap sub tipe DENV penyebab. Jika IgG dan IgM anti degue bersifat autoantibodi maka secara teoritis pasien dengan status serologis $\operatorname{IgM}(+)$ dan $\operatorname{IgG}(+)$ akan mempunyai profil hematologi yang lebih buruk dari pada pasien dengan $\operatorname{Ig} G(+)$.Penelitian ini bertujuan untuk mengetahui perbedaan profil hematologi menurut status serologi pada anak terinfeksi virus dengue. Penelitian menggunakan desian analitik dengan pendekatan cross sectional. Data diambil dari pasien anak di RSUD Surakarta dari bulan September 2016 - Januari 2017. Kriteria pasien yang diikutkan dalam penelitian adalah semua pasien anak dengan usia kurang dari 14 tahun dan memenuhi kriteria infeksi virus dengue menurut WHO 2009. Pasien dengan riwayat kelainan hematologi dan pasien dengan riwayat immunocompremised dikeluarkan dari penelitian.Hasil penelitian ditemukan 65 pasien dengan IVD yang memenuhi kriteria.Tujuh belas pasien dengan IgM dan IgG positif sedangkan sisanya hanya IgG positif Hasil penelitian perbedaan profil hematologi jumlah leukosit, trombosit, hematokrit, dan hemoglobin berdasarkan status $\operatorname{IgM}(+) \operatorname{IgG}(+)$ dengan $\operatorname{Ig} G(+)$ didapatkan nilai p masing-masing 0.833, 0,865, 0,137, 0,086, dan 0,223. Dapat disimpilkan bahwa tidak terdapat perbedaan profil hematologi antara pasien dengan $\operatorname{IgM}(+) \operatorname{Ig} G(+)$ dengan pasien $\operatorname{Ig} G(+)$.
\end{abstract}

Kata Kunci: infeksi virus dengue, antibodi anti dengue, autoantibodi, profil hematologi.

\section{ABSTRACT}

Anti-dengue antibodies are autoantibodies that can damage self antigens. Humoral immune response against $D E N V$ was played by specific IgM and IgG to DENVsub-type. If $\operatorname{Ig} G$ and IgM anti degue have autoantibodies property, then theoretically a patient with $\operatorname{IgM}(+)$ and $\operatorname{Ig} G(+)$ serologic status will have a worse hematological profile than in patients with $\operatorname{IgG}(+)$.The aim of this research is to know the differences of hematology profil based on serological status in children with dengue virus infection. Research analytic design using cross sectional approach. Data were taken from pediatric patients in RSUD Surakarta from September 2016 - January 2017. The criteria for patients included in the study were all pediatric patients younger than 14 years old and meet the criteria of dengue virus infections, according to WHO, 2009. Patients with a history of hematologic disorders and patients with immunocompremised history were excluded from the study. The research found 65 patients with IVD who meet the criteria. Seventeen patients have $\operatorname{IgM}$ and $\operatorname{IgG}$ positive while the rest have only IGG positive.P value of differences in the number of leukocytes, platelets, hematocrit, and hemoglobin status between $\operatorname{IgM}(+) \operatorname{Ig} G(+)$ and $\operatorname{IgG}(+)$ were $0833,0.865,0.137,0.086$, and 0.223 respectively. It can concluded that there is no difference between patients with hematological profile $\operatorname{IgM}(+) \operatorname{Ig} G(+)$ patients with $\operatorname{Ig} G(+)$.

Keywords : dengue virus infection, anti dengue antibody, autoantibody, hematology profiles.

\section{PENDAHULUAN}

Infeksi virus dengue (IVD) merupakan penyakit arboviralyang utama dan telah menyebar di 125 negara anggota World Health Organization (WHO) (Ferreira, 2012).Dilaporkan bahwajumlah penderita IVD mencapai 200 juta per tahun dengan angka morbiditas dan mortalitas yang relatif tinggi (Murray, Quam, Wilder-Smith., 2013). Angka sebenarnya dari IVD diperkirakan lebih banyak dari pada jumlah yang dilaporkan dan 
kasus IVD akan semakin banyak seiring dengan adanya pemanasan global (Bhattetal, 2013; Naish et al,2014)

Pathogenesis IVD hingga saat ini belum diketahui dengan jelas (de Azeredoet al, 2015). Berbagai teori dikemukakan untuk menjawab masalah ini termasuk teori autoimunitas (Wan et al, 2013).Antibodi anti dengue diketahui bereaksi silang dengan trombosit, endotel, dan faktor koagulasi.Pada kondisi ini antibodi anti dengue bersifat autoantibodi yang bisa merusak selfantigen(Huang et al, 2008; Liu et al, 2011).

Respon imun humoral terhadap DENV adalah terbentuknya IgM dan IgG yang spesifik terhadap sub tipe DENV penyebab (Wahala\& de Silva, 2011). Jika IgG dan IgM anti degue bersifat autoantibodi maka secara teoritis pasien dengan status serologis $\operatorname{IgM}(+)$ dan $\operatorname{IgG}(+)$ akan mempunyai profil hematologi yang lebih buruk dari pada pasien dengan $\operatorname{IgG}(+)$.Berdasarkan hal tersebut maka perlu dilakukan penelitian untuk mengetahui apakah ada perbedaan profil hematologi anak terinfeksi virus dengue status serologis $\operatorname{IgG}(+)$ dengan $\operatorname{IgG}$ dan $\operatorname{IgM}(+)$.

\section{METODE PENELITIAN}

Desain penelitian analitik dengan pendekatan cross sectional dipakai untuk menjawab pertanyaan penelitian.Data diambil dari pasien anak di RSUD Surakarta dari bulan September 2016 - Januari 2017. Kriteria pasien yang diikutkan dalam penelitian adalah semua pasien anak dengan usia kurang dari 14 tahun dan memenuhi kriteria infeksi virus dengue menurut WHO 2009. Pasien dengan riwayat kelainan hematologi dan pasien dengan riwayat immunocompremised dikeluarkan dari penelitian.

Pemeriksaan laboratorium dilakukan

di Laboratorium RSUD Surakarta.Sampel darah yang dipakai adalah darah vena dengan antikoagulan k3EDTA. Profil hematologi diperiksa menggunakan hematology analyzer Sysmex sedangkan antibodi antidengue menggunakan rapid dengue test (Mono IgM-IgG Tri Line Test. Masing-masing pemeriksaan dikerjakan sesuai dengan petunjuk penggunaan alat yang dikeluarkan oleh produsen. Data yang didapat dianalisa menggunakan bantuan software statistik.

\section{HASIL DAN PEMBAHASAN}

Selama 5 bulan penelitian didapatkan 80 pasien yang memenuhi kriteria infeksi virus dengue menurut WHO 2009.Sejumlah 15 pasien dikeluarkan dari penelitian karena data tidak memenuhi kriteria restriksi yang telah ditetapkan, sehingga didapatkan 65 pasien yang terlibat di dalam penelitian.Karakteristik pasien disajikan pada tabel 1 .

Tabel 1.Karakterisitik pasien berdasarakan status serologis

\begin{tabular}{cccc}
\hline Parameter hematologi & IgM (-), IgG (+) & IgM (+), IgG (+) & p \\
\hline Jenis Kelamin & & & $0,296^{*}$ \\
Laki-laki (\%) & 24 & 11 & \\
Wanita(\%) & 24 & 6 & \\
Umur (tahun) & $8.5(0,3-13)^{\#}$ & $7(0,3-13)^{\#}$ & $0,833^{* *}$ \\
Lekosit $\left(/ \mathrm{ml}^{3}\right)$ & $5.514(2,46)^{\$}$ & $5.391(2,19)^{\$}$ & $0,865^{* * *}$ \\
Trombosit $\left(/ \mathrm{ml}^{3}\right)$ & $73.854(40,14)^{\$}$ & $98.000(62,99)^{\$}$ & $0,137^{* *}$ \\
Hematokrit $(\%)$ & $37(30-55)^{\#}$ & $36(30-45)^{\#}$ & $0,086^{* *}$ \\
Hemoglobin $(\mathrm{gr} / \mathrm{dl})$ & $12,7(8,3-16,8)^{\#}$ & $12,5(10,3-15,6)^{\#}$ & $0,223^{* *}$ \\
\hline
\end{tabular}

Keterangan $: *=$ median $\left(\right.$ min-maks), ${ }^{s}=$ mean $(S D),{ }^{*}=$ Chi Square, ${ }^{* *}=$ Mann-Witney, ${ }^{* * *}=$ Independent T test

Immunoglobulin $\mathrm{M}$ dan $\operatorname{IgG}(+)$ dan hanya IgG anti dengue yang $(+)$ menunjukkan bahwa pasien yang terlibat dalam penelitian adalah pasien dengan IVD sekunder. Menurut panduan pembacaan hasil rapid test disebutkan bahwa setiap pasien dengan IgG anti dengue $(+)$ termasuk ke dalam kategori IVD sekunder (Subdirektorat Pengendalian Arbovirosis-Dit PPBB-Ditjen PP dan PL., 2011). Immunoglobulin M yang (+) pada pasien dengan IVD sekunder bisa berarti pasien terinfeksi sekunder oleh serotipe DENV yang sama ataupun oleh serotipe berbeda.

Pasien yang terlibat di dalam penelitian tidak ada yang terdiagnosis sebagai IVD primer. Hal ini disimpulkan berdasarkan tidak adanya hasil pemeriksaan serologis yang hanya $\operatorname{IgM}(+)$.Hasil ini mendukung teori yang meyakini bahwa infeksi sekunder biasanya lebih berat daripada infeksi 
primer karena adanya antibodi non netralisasi dari infeksi sebelumnya (Halstead, 2012).Infeksi sekunder yang lebih berat mendorong pasien atau keluarga pasien mencari pertolongan.

Tabel 1 menunjukkan bahwa jenis kelamin tidak berpengaruh dengan status serologis.Hasil ini terjadi karena repson imun humoral dan seluler dipengaruhi oleh hormon kelamin, sedangkan penelitian dilakukan pada pasien yang belum baligh. Kadar hormon kelamin pada anak yang belum balighrelatif tidak berbeda antara laki-laki dan perempuan, sehingga menyebabkan kadar antibodi sebagai perwujudan imunitas humoral tidak berbeda antara laki-laki dan perempuan (Nguyen, 2014).

Umur subyek penelitian tidak berpengaruh dalam status serologis $P=0,833$. Terdapat beberapa penyebab tidak ada kaitan antara usia dengan status serologis pasien IVD. Sitokin dan riwayat infeksi berat di awal kehidupan mengurangi kemampuan membentuk antibodi. Pasien IVD yang tidak berat dan infeksi ulang dengan serotipe yang sama cenderung membentuk sel Treg yang menghasilkan TGF- $\beta$ dan IL10. Kedua sitokin ini bersifat anti inflamasi dan menghambat pembentukan antibodi (Chaturvedi et al, 2007; Jayaratne et al, 2016; Sierra et al, 2010). Rendahnya status sosial menyebabkan pasien mudah terkena infeksi. Infeksi yang terjadi pada awal kehidupan akan memicu pembentukan sel Treg untuk mengatur respon imun agar tidak merusak tubuh. Sel Treg tersebut akan menekan produksi antibodi ketika terinfeksi oleh DENV dikemuadian hari (Bach, 2005).

Hasil penelitian menunjukkan tidak ditemukan adanya leukopenia pada pasien IVD. Hal ini sesuai dengan penelitian Banerjee et al (2008) dan Jatmiko (2016).Leukopenia terjadi pada pasien dengan IVD berat seperti yang dilaporkan oleh (Hartoyo, 2008).Perjalanan penyakit IVD juga mempengaruhi jumlah leukosit. Pada awal perjalanan penyakit, IVD biasa didahlui dengan leukositosis dan akan menjadi leukopenia di akhir perjalanan IVD (Azin et al, 2012). Leukopenia lebih berkaitan dengan derajat IVD dan perjalanan penyakit daripada dengan status serologis, sehingga hasil penelitian menunjukkan tidak adanya perbedaan jumlah leukosit antara kedua status serologis dengan $\mathrm{p}=0,865$.

Jumlah trombosit dari subyek penelitian mengalami penurunan, baik yang $\operatorname{IgM}(-) / \operatorname{IgG}$
(+) maupun IgM (+)/IgG (+).Trombositopenia menjadi salah satu kriteria diagnostik dari IVD, sehingga semua penelitian tentang IVD melaporkan terjadinya trombositopenia. Hasil penelitian ini menunjukkann tidak terdapat perbedaan jumlah trombosit antara pasien dengan $\operatorname{IgM}(-) / \operatorname{IgG}(+)$ maupun IgM (+)/IgG (+) dengan $p=0,137$. Penyebabkondisi ini adalah banyaknya faktor yang mempengaruhi hasil jumlah trombosit pada pasien IVD.Infeksi megakaryosit, supresi sumsum tulang, destruksi trombosit, sekuestrasi trombosit, dan apoptosis trombosit mempengaruhi jumlah trombosit pada pasien IVD (Jatmiko, 2016). Antibodi anti dengue ditemukan bereaksi silang dengan platelet dan endotel sehingga bisa mempengaruhi jumlah trombosit (Huang et al, 2008; Liu et al, 2011), akan tetapi faktor yang lain juga mempengaruhi jumlah trombosit. Faktorfaktor lain tersebut bisa jadi mempengaruhi hasil penelitian ini.

Hematokrit dan hemoglobin biasa ditemukan meningkat pada pasien IVD berat / demam berdarah dengue (DBD) (Azin et al, 2012). Mengingat bahwa tidak ada pasien kami yang terkategorikan sebagai DBD maka ditemukan hasil penelitian yang tidak ada perbedaan kadar hemoglobin dan nilai hematokrit antara pasien dengan $\operatorname{IgM}(-) / \operatorname{IgG}(+)$ maupun $\operatorname{IgM}(+) / \operatorname{IgG}(+)$ dengan $\mathrm{p}$ masing-masing 0,086 dan 0,223.

Penelitian ini secara umum menunjukkan bahwa tidak ada perbedaan profil hematologi antara pasien dengan $\operatorname{IgM}(-) / \operatorname{IgG}(+)$ maupun $\operatorname{IgM}(+) / \operatorname{IgG}(+)$. Hasil ini tidak menunjukkan bahwa antibodi anti dengue tidak berperan dalam terjadinya perubahan parameter hematologi pasien IVD. Pernyataan ini didukung dengan kenyataaan bahwa 1) beberapa hasil penelitian mengkonfirmasi adanya reaksi silang antara antibodi anti dengue dengan trombosit dan endotel (Huang et al, 2008; Liu et al, 2011), 2) seluruh pasien yang terlibat adalah pasien IVD dengan warningsignsehingga lebih banyak menghasilkan TGF- $\beta$ yang cenderung menekan inflamasi (Chaturvedi et al, 2007; Jayaratneet al, 2016; Sierraet al, 2010), 3) pada infeksi sekunder ditemukan kadar IgG anti dengue yang jauh lebih tinggi dari pada IgM sehingga pada infeksi sekunder IgG lebih berpengaruh dari pada IgM (Subdirektorat Pengendalian Arbovirosis-Dit PPBB-Ditjen PP dan PL., 2011). 


\section{SIMPULAN DAN SARAN}

Berdasarkan penelitian yang telah dilakukan maka dapat diambil kesimpulan bahwa status serologis pasien IVD tidak berhubungan dengan profil hematologi, terutama pada pasien anak terinfeksi virus dengue dengan warning sign.

Pembahasan hasil penelitian menunjukkan beberapa keterbatasan yang bisa diperbaiki pada penelitian selanjutnya. Diantara saran yang bisa diajukan untuk memperbaiki keterbatasan adalah perlu dilakukan penelitian dengan variabel yang sama pada beberapa derajat IVD untuk mengetahui adanya pengaruh status serologis dengan profil hematologi pada pasien IVD sesuai derajat penyakit, dan perlu dilakukan penelitian dengan variabel yang sama pada pasien IVD primer dan sekunder untuk mengetahui pengaruh IgM pada profil hematologi pasien IVD.

\section{DAFTAR PUSTAKA}

Azin FRFG, Gonçalves RP, Pitombeira MHD, Lima DM, Branco IC., 2012.Dengue: profile of hematological and biochemical dynamics. Rev Bras Hematol Hemoter.34(1):36-41

Bach JF., 2005. Infections and autoimmune diseases.J Autoimmun, 25:74-80

BanerjeeM,ChatterjeeT,Choudhary GS,SrinivasV,KatariaBVK.,2008.Dengue:AClinicohaematological Profile. MJAFI; 64: 333-6

Bhatt S, Gething PW, Brady OJ, Messina P, Farlow AW, Moyes CL, et al, 2013. The global distribution and burden of dengue.Nature.;496(7446): 504-7

Chaturvedi UC, Shrivastava R, Tripathi RK, Nagar R., 2007. Dengue virus-spesific suppressor T cells: current perspectives. FEMS Immunol Med Microbiol,50:285-99

de Azeredo EL, Monteiro RQ, Pinto LMD., 2015. Thrombocytopenia in Dengue: Interrelationship between Virus and the Imbalance between Coagulation and Fibrinolysis and Inflammatory Mediators. Mediators of Inflammation. 313842

Ferreira GLC., 2012. Global Dengue Epidemiology Trends.Rev Inst Med Trop,54;(Suppl. 18):S5-6 Halstead SB, 2012. Controversies in dengue pathogenesis.Paediatrics Int Child Health, 32;S1: 5-9

Hartoyo E. 2008. Spektrum Klinis Demam Berdarah Dengue pada anak.Sari Pediatri, 10(3):145-50

Huang KJ, Lin YS, Liu HS, Yeh TM, Liu CC, Lei HY., 2008. Generation of Anti-platelet Autoantibody During Dengue Virus Infection. Am J Infect Dis, 4 (1): 50-9

Jatmiko SW. 2016. Hubungan Kadar Rheumatoid Factor dengan Perubahan Jumlah Trombosit dan Nilai Hematokrit pada Anak Terinfeksi Virus Dengue. Semarang: Universitas Diponegoro (Thesis). 1-58

Jayaratne HE, Wickramasinghe N, Adikari TN, Gomes L, Kamaladasa A, Ogg GS, etal., 2016. Expansion of regulatory $\mathrm{T}$ cells in acute dengue infection does not associate with disease severity. Int $J$ Infect Dis,;45S:1-477

Liu IJ, Chiu CY, Chen YC, Wu HC., 2011. Molecular Mimicry of Human Endothelial Cell Antigen by Autoantibodies to Nonstructural Protein 1 of Dengue Virus.J Biol Chem, 286(11): 9726-36

Murray NEA, Quam MB, Wilder-Smith A., 2013.Epidemiology of dengue: past, present and future prospects. Clin Epidemiol, 5: 299-309

Naish S, Dale P, Mackenzie JS, McBride J, Mengersen K, Tong S., 2014.Climate change and dengue: a critical and systematic review of quantitative modelling approaches. BMC Infect Dis, 14:167

Nguyen PV, Kafka JK, Ferreira VH, Roth k, Kaushic C., 2014. Innate and adaptive immune responses in male and female reproductive tracts in homeostasis and following HIV infection.Cell Mol Immunol,11: 410-27

Sierra B, Perez AB, Vogt K, Garcia G, Schmolke K, Aquirre E, et al., 2010. Secondary heterologues dengue infection risk:Disequilibrum between immune regulation and inflammation? Cellimmunol,262:134-40

Subdirektorat Pengendalian Arbovirosis-Dit PPBB-Ditjen PP dan PL., 2011.Petunjuk TeknisPenggunaan 
Rapid Diagnostic Test (RDT) Untuk Penunjang Diagnosis Dini DBD. Jakarta:Kementerian Kesehatan RI.1-11

Wahala WMPB, de Silva AM., 2011. The Human Antibody Response to Dengue Virus Infection.Viruses, 3, 2374-95

Wan SW, Lin CF, Yeh TM, Liu CC, Liu HS, Wang S, et al., 2013.Autoimmunity in dengue pathogenesis. J Form Med Assoc,; 112: 3-11 